\title{
Implementasi Metode ANP Terhadap Sistem Pendukung Keputusan Memilih Toko Daring Terbaik
}

\author{
Romindo, Jamaludin \\ Prodi Manajemen Informatika, Politeknik Ganesha, Medan, Indonesia \\ Email: ${ }^{1}$ romindo4@gmail.com, jamaludinmedan@gmail.com
}

\begin{abstract}
Abstrak
Saat ini toko daring banyak diminati dikalangan masyarakat Indonesia. Lazada, Shopee, Buka Lapak merupakan beberapa toko daring yang cukup populer di Indonesia. Mahasiswa Politeknik Ganesha adalah sebagian kecil masyarakat Indonesia yang hobi berbelanja di toko daring. Terjadi perdebatan dan perbincangan dikalangan mahasiswa Politeknik Ganesha, dalam hal ini perbedatan yang dilakukan adalah membandingkan Toko daring mana yang terbaik. Perdebatan tersebut menjadi tujuan dalam penelitian ini. SuperDecisions adalah sebuah sistem pendukung keputusan yang menjadi kebutuhan penting dalam proses pemilihan toko daring terbaik. Dalam proses pemilihan toko daring peneliti juga menggunakan metode Analytical Network Process (ANP) sebagai pemodelan masalah terhadap keputusan yang kompleks. Hasil prose penerapan metode ANP terhadap proses sistem pendukung keputusan menyimpulkan bahwa Shopee merupakan toko daring terbaik menurut mahasiswa Politeknik Ganesha dengan bobot 3.80, dilanjutkan dengan Buka Lapak dengan bobot 3.73 dan Lazada dengan bobot 2.47.
\end{abstract}

Kata Kunci: Toko Daring, SuperDecisions, ANP, Politeknik Ganesha

\section{Abstract}

Today, online shops are in great demand by the people of Indonesia. Lazada, Shopee, Buka Lapak are a number of online stores that are quite popular in Indonesia. Students of the Ganesha Polytechnic are a small part of Indonesian people who are interested in buying at online stores. There is an increase and discussion among the Polytechnic students of Ganesha, in this case the difference is comparing which shops are the best. This debate is the purpose of this study. SuperDecisions is a decision support system which is an important requirement in the process of selecting the best online store. In the process of selecting a store, researchers also dare to use the Analytical Network Process (ANP) method as a problem modeling for complex results. The results of applying the ANP method to Shopee's decision process are the best online stores according to 3.80 Ganesha Polytechnic students, followed by Buka Lapak weighing 3.73 and Lazada with a weight of 2.47.

Keywords: Online Shop, Super Decisions, ANP, Ganesha Polytechnic

\section{PENDAHULUAN}

Perkembangan sistem informasi saat ini sedemikian pesat. Pesatnya sistem informasi berbanding lurus dengan metode komputasi yang digunakan. Salah satu metode komputasi yang cukup berkembang adalah metode sistem pendukung keputusan (Decisions Support System). Dalam teknologi informasi, sistem pendukung keputusan merupakan cabang ilmu yang letaknya diantara sistem informasi dan sistem kecerdasan buatan.

Toko online berasal dari dua suku kata, yakni toko dan online. Menurut Kamus Besar Bahasa Indonesia, toko berarti sebuah tempat atau bangunan permanen untuk menjual barang-barang (makanan, minuman, dan sebagainya). Sedangkan online pada terjemahan bahasa Indonesianya adalah dalam jaringan atau disingkat daring menurut wikipedia adalah keadaan di saat seseorang terhubung ke dalam suatu jaringan atau sistem yang lebih besar. Jadi berangkat dari dua pengertian secara bahasa tersebut kita dapat mengartikan toko online sebagai tempat terjadinya aktivitas perdangan atau jual beli barang yang terhubung ke dalam suatu jaringan dalam hal ini jaringan internet[1].

Saat ini Toko daring dari sebagian perusahaan merupakan bagian dari nilai keunggulan dalam persaingan competitive advantage saat ini. Perusahaan menggunakan Toko daring sebagai pegembangan pemasaran, pengiriman, pelayanan, dan pembayaran pelanggan. Perkembangan toko daring diIndonesia sendiri telah ada sejak tahun 1996, hingga saat ini toko daring yang cukup populer saat ini di Indonesia diantaranya Lazada, Shopee, blibli, tokopedia, bukalapak dan lain-lain[2].

Pengguna internet Indonesia tercatat sebagai warganet yang paling banyak membeli barang secara online pada Desember 2018. Sebanyak 86\% pengguna internet Indonesia melakukan belanja online lewat perangkat apapun, sementara itu, China menduduki posisi ke-2 dengan $82 \%$ pengguna internet mereka yang melakukan belanja online lewat perangkat apapun. Jerman dan Inggris di peringkat 3 dan 4 dengan persentase yang sama yaitu $81 \%$. Sementara Thailand ada di tempat kelima dengan $80 \%$. Tingkat belanja online pengguna internet Indonesia adalah yang tertinggi dibanding negara di kawasan Asia Tenggara lain. Hanya $77 \%$ pengguna internet Vietnam yang melakukan belanja online, disusul Malaysia 75\%, Singapura 73\%, dan Filipina $70 \%$. Sementara rata-rata belanja online para pengguna internet dunia sebesar 75\%[3].

Politeknik Ganesha adalah salah satu kampus swasta di Indonesia dengan mahasiswa yang memiliki hobi berbelanja di Toko daring. Dikalangan mahasiswa Politeknik Ganesha sering kali memperbincangkan dan memperdebatkan kelebihan atau kekurangan beberapa Toko daring langganannya. Hal ini yang menjadi dasar penelitian untuk lebih mendalami beberapa Toko daring yang diminati oleh mahasiswa Politeknik Ganesha. Penelitian yang dilakukan bertujuan untuk menentukan keputusan memilih toko daring terbaik. 
Proses pemilihan toko daring terbaik yang dilakukan menggunakan sebuah software yang bernama SuperDecisions. SuperDecisions adalah sistem pendukung keputusan (decision support systems disingkat DSS) yang dimana merupakan bagian dari sistem informasi berbasis komputer dan termasuk sistem berbasis pengetahuan (manajemen pengetahuan) yang dipakai untuk mendukung pengambilan keputusan dalam suatu organisasi perusahaan,atau lembaga pendidikan. Dapat juga dikatakan sebagai sistem komputer yang mengolah data menjadi informasi untuk mengambil keputusan dari masalah yang spesifik[4].

Sistem Pendukung Keputusan memiliki beberapa metode, diantaranya: Simple Additive Weighting, Weighted Product, Technique for Order by Similarity to Ideal Solution, Multi-Objective Optimization on the basis of Ratio Analysis, Complex Proportional Assessment, dan lain-lain. Namun dalam penelitian ini metode Analytic Network Process (ANP) menjadi metode yang menarik dalam memilih toko daring terbaik. Analytic Network Process (ANP) adalah bentuk yang lebih umum dari Analytic Hierarchy Process(AHP), yang menggabungkan umpan balik dan hubungan saling ketergantungan antar elemen keputusan dan alternatif. Hal ini memberikan pendekatan yang lebih akurat ketika memodelkan masalah keputusan yang kompleks. AHP adalah kasus khusus dari ANP. Baik AHP dan ANP menurunkan skala prioritas relatif angka mutlak dari penilaian individu dengan membuat perbandingan berpasangan dari elemen-elemen pada properti umum atau kriteria kontrol[5].

Penelitian terdahulu dengan judul "Analisa Perbandingan Metode ANP dan SAW dalam menentukan mahasiswa terbaik" pada JIPN (Journal Of Informatics Pelita Nusantara) Volume 4 Nomor 1, Maret 2019 ISSN: 2541-3724. Penelitian ini membahas tentang perbandingan 2 metode ANP dengan SAW, proses perbandingan metode ini dilakukan pada studi kasus penentuan mahasiswa terbaik. Hasil penelitian ini menyimpulkan bahwa metode ANP lebih baik daripada SAW[6].

Berdasarkan permasalahan yang terjadi dikalangan mahasiswa Politeknik Ganesha tentang penentuan toko daring terbaik, maka penelitian ini dilakukan dengan menggunakan Sistem Pendukung Keputusan dan Analytic Network Process (ANP) sebagai metode yang digunakan untuk pemodelan masalah keputusan yang kompleks.

\section{METODE PENELITIAN}

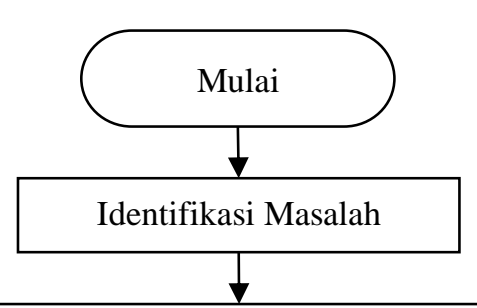

Pengumpulan Data:

1. Data Alternatif yaitu: Lazada, Shopee dan Bukalapak.

2. Data Kriteria yaitu: Logo, Gratis Ongkos Kirim, Berita Terbaru, Produk Popular, Merk Produk, Pembayaran Sistem Icon, Sosial Media Link, Nomor telefon/Chating Online, Toko Finder dan Trusmark

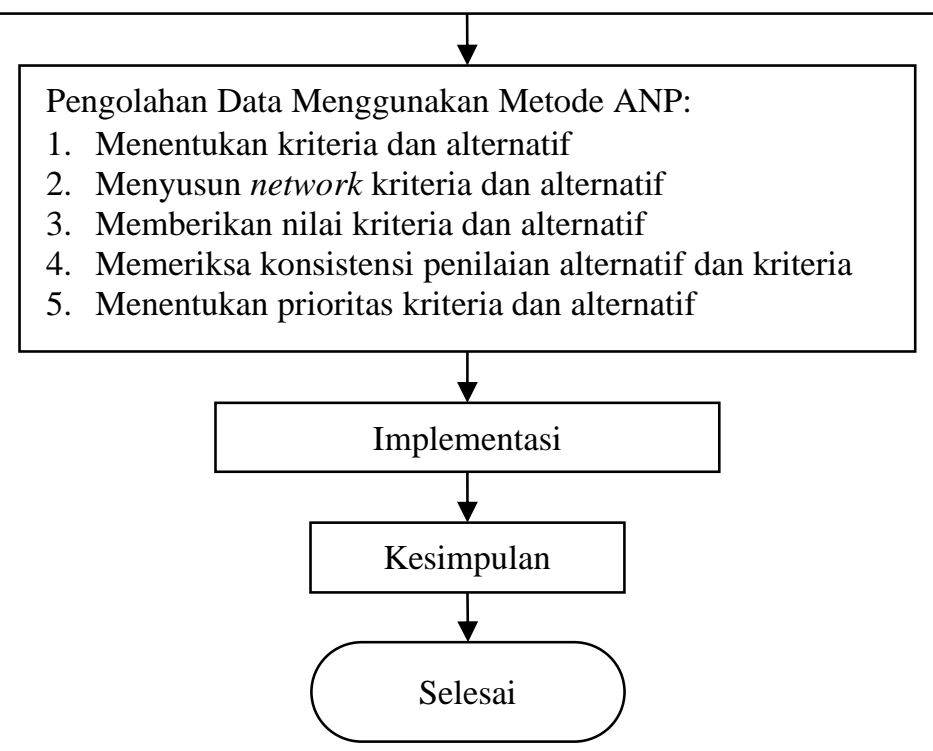

Gambar 1. Metode Penelitian 


\section{ANALISA DAN PEMBAHASAN}

1. Penentuan Kriteria dan Sub Kriteria

Penentuan kriteria dan sub kriteria diperoleh berdasarkan hasil pengisian angket yang berikan kepada mahasiswa/i Politeknik Ganesha. Hasil pengisian angket tersebut mendapatkan 10 kriteria dan 3 alternatif yang digunakan pada penentuan toko daring terbaik. Kriteria-kriteria yang terpilih dapat dilihat pada tabel 1 dan alternatif yang terpilih dapat dilihat pada tabel 2. Berdasarkan identifikasi keterkaitan antar kriteria dapat diketahui bahwa dalam menentukan toko daring terbaik menggunakan kriteria yang saling terkait. Maka metode yang tepat digunakan untuk menentukan toko daring terbaik adalah metode Analytical Network Process.

Tabel 1. Kriteria

\begin{tabular}{cl}
\hline No & \multicolumn{1}{c}{ Kriteria } \\
\hline 1 & Nomor telefon/Chating Online (NT) \\
2 & Produk Popular (PP) \\
3 & Gratis Ongkos Kirim (GOK) \\
4 & Sistem Pembayaran (SP) \\
5 & Logo (L) \\
6 & Sosial Media Link (SML) \\
7 & Toko Finder (TF) \\
8 & Merk Produk (MP) \\
9 & Berita Terbaru (BT) \\
10 & Trusmark (T) \\
\hline
\end{tabular}

Tabel 2. Alternatif

\begin{tabular}{cll}
\hline No & & Alternatif \\
\hline 1 & Lazada & \\
2 & Shopee & \\
3 & BukaLapak & \\
\hline
\end{tabular}

2. Analisis bobot kriteria

Setelah menentukan kriteria dan alternatif yang tepat dalam menentukan Toko Daring terbaik, maka mahasiswa Politeknik Ganesha kembali mengisi angket guna menentukan bobot tertinggi hingga terendah dengan perbandingan berpasangan terhadap antar kriteria. Penentuan bobot tersebut dilakukan dengan menggunakan angket yang tersedia didalam sistem pendukung keputusan yang disebut dengan SuperDecisions. Proses perbandingan berpasangan dapat dilihat pada tabel 3.

Tabel 3. Perbandingan Berpasangan

\begin{tabular}{ccccccccccc}
\hline Kriteria & NT & PP & GOK & SP & L & SML & TF & MP & BT & T \\
\hline NT & 1 & 2 & $1 / 2$ & $1 / 2$ & 3 & 3 & 4 & 2 & 3 & 3 \\
PP & $1 / 2$ & 1 & $1 / 3$ & $1 / 2$ & 3 & 3 & 3 & 2 & 2 & 2 \\
GOK & 2 & 3 & 1 & 2 & 4 & 3 & 4 & 2 & 3 & 3 \\
SP & 2 & 2 & $1 / 2$ & 1 & 3 & 2 & 3 & 2 & 2 & 2 \\
L & $1 / 3$ & $1 / 3$ & $1 / 4$ & $1 / 3$ & 1 & $1 / 2$ & 2 & $1 / 2$ & $1 / 2$ & $1 / 3$ \\
SML & $1 / 3$ & $1 / 3$ & $1 / 3$ & $1 / 2$ & 2 & 1 & 2 & $1 / 2$ & $1 / 2$ & $1 / 3$ \\
TF & $1 / 4$ & $1 / 3$ & $1 / 4$ & $1 / 3$ & $1 / 2$ & $1 / 2$ & 1 & $1 / 3$ & $1 / 2$ & $1 / 2$ \\
MP & $1 / 2$ & $1 / 2$ & $1 / 2$ & $1 / 2$ & 2 & 2 & 3 & 1 & 2 & 2 \\
BT & $1 / 3$ & $1 / 2$ & $1 / 3$ & $1 / 2$ & 2 & 2 & 2 & $1 / 2$ & 1 & $1 / 4$ \\
T & $1 / 3$ & $1 / 2$ & $1 / 3$ & $1 / 2$ & 3 & 3 & 2 & $1 / 2$ & 4 & 1 \\
\hline
\end{tabular}

Kemudian matriks perbandingan berpasangan pada tabel 3 dievaluasi dan dijumlahkan setiap kolomnya sehingga mendapatkan hasil seperti ditunjukkan pada tabel 4.

Tabel 4. Evaluasi Perbandingan Berpasangan

\begin{tabular}{ccccccccccc}
\hline Kriteria & NT & PP & GOK & SP & L & SML & TF & MP & BT & T \\
\hline NT & 1.00 & 2.00 & 0.50 & 0.50 & 3.00 & 3.00 & 4.00 & 2.00 & 3.00 & 3.00 \\
PP & 0.50 & 1.00 & 0.33 & 0.50 & 3.00 & 3.00 & 3.00 & 2.00 & 2.00 & 2.00 \\
GOK & 2.00 & 3.00 & 1.00 & 2.00 & 4.00 & 3.00 & 4.00 & 2.00 & 3.00 & 3.00 \\
SP & 2.00 & 2.00 & 0.50 & 1.00 & 3.00 & 2.00 & 3.00 & 2.00 & 2.00 & 2.00 \\
L & 0.33 & 0.33 & 0.25 & 0.33 & 1.00 & 0.50 & 2.00 & 0.50 & 0.50 & 0.33 \\
SML & 0.33 & 0.33 & 0.33 & 0.50 & 2.00 & 1.00 & 2.00 & 0.50 & 0.50 & 0.33 \\
TF & 0.25 & 0.33 & 0.25 & 0.33 & 0.50 & 0.50 & 1.00 & 0.33 & 0.50 & 0.50 \\
MP & 0.50 & 0.50 & 0.50 & 0.50 & 2.00 & 2.00 & 3.00 & 1.00 & 2.00 & 2.00 \\
\hline
\end{tabular}




\begin{tabular}{ccccccccccc}
\hline Kriteria & NT & PP & GOK & SP & L & SML & TF & MP & BT & T \\
\hline BT & 0.33 & 0.50 & 0.33 & 0.50 & 2.00 & 2.00 & 2.00 & 0.50 & 1.00 & 0.25 \\
T & 0.33 & 0.50 & 0.33 & 0.50 & 3.00 & 3.00 & 2.00 & 0.50 & 4.00 & 1.00 \\
Jumlah & 7.57 & 10.49 & 4.32 & 6.66 & 23.5 & 20 & 26 & 11.33 & 18.5 & 14.41 \\
\hline
\end{tabular}

Setelah itu jumlah kolomnya ditentukan, angka-angka dalam matriks 10 x 10 tersebut dibagi dengan jumlah kolomnya masing-masing sehingga menghasilkan matriks 10 x 10 hasil penjumlahan kolom. Hasil penjumlahan kriteria dapat dilihat pada tabel 5.

Tabel 5. Hasil Penjumlahan Kriteria

\begin{tabular}{cccccccccccc}
\hline Kriteria & NT & PP & GOK & SP & L & SML & TF & MP & BT & T & Jumlah \\
\hline NT & 0.13 & 0.19 & 0.12 & 0.08 & 0.13 & 0.15 & 0.15 & 0.18 & 0.16 & 0.21 & 1.49 \\
PP & 0.07 & 0.10 & 0.08 & 0.08 & 0.13 & 0.15 & 0.12 & 0.18 & 0.11 & 0.14 & 1.13 \\
GOK & 0.26 & 0.29 & 0.23 & 0.30 & 0.17 & 0.15 & 0.15 & 0.18 & 0.16 & 0.21 & 2.10 \\
SP & 0.26 & 0.19 & 0.12 & 0.15 & 0.13 & 0.10 & 0.12 & 0.18 & 0.11 & 0.14 & 1.49 \\
L & 0.04 & 0.03 & 0.06 & 0.05 & 0.04 & 0.03 & 0.08 & 0.04 & 0.03 & 0.02 & 0.42 \\
SML & 0.04 & 0.03 & 0.08 & 0.08 & 0.09 & 0.05 & 0.08 & 0.04 & 0.03 & 0.02 & 0.53 \\
TF & 0.03 & 0.03 & 0.06 & 0.05 & 0.02 & 0.03 & 0.04 & 0.03 & 0.03 & 0.03 & 0.35 \\
MP & 0.07 & 0.05 & 0.12 & 0.08 & 0.09 & 0.10 & 0.12 & 0.09 & 0.11 & 0.14 & 0.94 \\
BT & 0.04 & 0.05 & 0.08 & 0.08 & 0.09 & 0.10 & 0.08 & 0.04 & 0.05 & 0.02 & 0.62 \\
T & 0.04 & 0.05 & 0.08 & 0.08 & 0.13 & 0.15 & 0.08 & 0.04 & 0.22 & 0.07 & 0.93 \\
\hline
\end{tabular}

Skala bobot prioritas didapat dengan cara menghitung rata-rata baris dari matriks $10 \mathrm{x} 10$, hasil perhitungan dapat dilihat pada tabel 6 .

Tabel 6. Skala Pembobotan Perbandingan Berpasangan

\begin{tabular}{|c|c|c|c|c|c|c|c|c|c|c|c|}
\hline Kriteria & NT & PP & GOK & SP & $\mathrm{L}$ & SML & $\mathrm{TF}$ & MP & BT & $\mathrm{T}$ & $\begin{array}{c}\text { Priority } \\
\text { Vector }\end{array}$ \\
\hline NT & 1.00 & 2.00 & 0.50 & 0.50 & 3.00 & 3.00 & 4.00 & 2.00 & 3.00 & 3.00 & 0.15 \\
\hline PP & 0.50 & 1.00 & 0.33 & 0.50 & 3.00 & 3.00 & 3.00 & 2.00 & 2.00 & 2.00 & 0.11 \\
\hline GOK & 2.00 & 3.00 & 1.00 & 2.00 & 4.00 & 3.00 & 4.00 & 2.00 & 3.00 & 3.00 & 0.21 \\
\hline SP & 2.00 & 2.00 & 0.50 & 1.00 & 3.00 & 2.00 & 3.00 & 2.00 & 2.00 & 2.00 & 0.15 \\
\hline $\mathrm{L}$ & 0.33 & 0.33 & 0.25 & 0.33 & 1.00 & 0.50 & 2.00 & 0.50 & 0.50 & 0.33 & 0.04 \\
\hline SML & 0.33 & 0.33 & 0.33 & 0.50 & 2.00 & 1.00 & 2.00 & 0.50 & 0.50 & 0.33 & 0.05 \\
\hline $\mathrm{TF}$ & 0.25 & 0.33 & 0.25 & 0.33 & 0.50 & 0.50 & 1.00 & 0.33 & 0.50 & 0.50 & 0.03 \\
\hline MP & 0.50 & 0.50 & 0.50 & 0.50 & 2.00 & 2.00 & 3.00 & 1.00 & 2.00 & 2.00 & 0.09 \\
\hline BT & 0.33 & 0.50 & 0.33 & 0.50 & 2.00 & 2.00 & 2.00 & 0.50 & 1.00 & 0.25 & 0.06 \\
\hline $\mathrm{T}$ & 0.33 & 0.50 & 0.33 & 0.50 & 3.00 & 3.00 & 2.00 & 0.50 & 4.00 & 1.00 & 0.09 \\
\hline & 1.00 \\
\hline \multicolumn{11}{|c|}{ Principal Eigen Value } & 10.72 \\
\hline \multicolumn{11}{|c|}{ Consistency Index } & 0.08 \\
\hline \multicolumn{11}{|c|}{ Consistency Rasio } & 0.54 \\
\hline
\end{tabular}

Proses perhitungan pada tabel 6 dapat dijelaskan sebagai berikut:

a. Jumlah merupakan penjumlahan dari semua angka yang ada pada baris diatasnya dalam satu kolom.

b. Priority Vector merupakan hasil penjumlahan dari semua sel disebelah kirinya (pada baris yang sama) setelah terlebih dahulu dibagi dengan jumlah yang ada dibawahnya, kemudian hasil penjumlahan tersebut dibagi dengan angka.

c. Angka 10 diperoleh dari jumlah kriteria yaitu Nomor Telpon/Chatting Online (NT), Produk Popular (PP), Gratis Ongkos Kirim (GOK), Sistem Pembayaran (SP), Logo (L), Sosial Media Link (SML), Toko Finder (TF), Merk Produk (MP), Berita Terbaru (BT) dan Trusmark (T).

d. Priority vector Nomor Telpon/Chatting Online $(\mathrm{NT})=0.15$ diperoleh dari $((1 / 7.57)+(2 / 10.49)+(0.5 / 4.32)+$ $(0.5 / 6.66)+(3 / 23.5)+(3 / 20)+(4 / 26)+(2 / 11.33)+(3 / 18.5)+(3 / 14.41) * 1 / 10$

e. Priority Vector Produk Popular $(\mathrm{PP})=0.11$ diperoleh dari $((0.5 / 7.57)+(1 / 10.49)+(0.33 / 4.32)+(0.5 / 6.66)+$ $(3 / 23.5)+(3 / 20)+(3 / 26)+(2 / 11.33)+(2 / 18.5)+(2 / 14.41) * 1 / 10$

f. Priority Vector Gratis Ongkos Kirim $(\mathrm{GOK})=0.21$ diperoleh dari $((2 / 7.57)+(3 / 10.49)+(1 / 4.32)+(2 / 6.66)+$ $(4 / 23.5)+(3 / 20)+(4 / 26)+(2 / 11.33)+(3 / 18.5)+(3 / 14.41) * 1 / 10$

g. Priority Vector Sistem Pembayaran $(\mathrm{SP})=0.15$ diperoleh dari $((2 / 7.57)+(2 / 10.49)+(0.5 / 4.32)+$ $(1 / 6.66)+(3 / 23.5)+(2 / 20)+(3 / 26)+(2 / 11.33)+(2 / 18.5)+(2 / 14.41) * 1 / 10$

h. Priority Vector $\operatorname{Logo}(\mathrm{L})=0.04$ diperoleh dari $((0.33 / 7.57)+(0.33 / 10.49)+(0.25 / 4.32)+(0.33 / 6.66)+(1 / 23.5)$ $+(0.5 / 20)+(2 / 26)+(0.5 / 11.33)+(0.5 / 18.5)+(0.33 / 14.41) * 1 / 10$

i. Priority Vector Sosial Media Link $(S M L)=0.05$ diperoleh dari $((0.33 / 7.57)+(0.33 / 10.49)+(0.33 / 4.32)+$ $(0.5 / 6.66)+(2 / 23.5)+(1 / 20)+(2 / 26)+(0.5 / 11.33)+(0.5 / 18.5)+(0.33 / 14.41) * 1 / 10$ 
j. Priority Vector Toko Finder $(\mathrm{TF})=0.03$ diperoleh dari $((0.25 / 7.57)+(0.33 / 10.49)+(0.25 / 4.32)+$ $(0.33 / 6.66)+(0.5 / 23.5)+(0.5 / 20)+(1 / 26)+(0.33 / 11.33)+(0.5 / 18.5)+(0.5 / 14.41) * 1 / 10$

k. Priority Vector Merk Produk $(\mathrm{MP})=0.09$ diperoleh dari $((0.5 / 7.57)+(0.5 / 10.49)+(0.5 / 4.32)+$ $(0.5 / 6.66)+(2 / 23.5)+(2 / 20)+(3 / 26)+(1 / 11.33)+(2 / 18.5)+(2 / 14.41) * 1 / 10$

1. Priority Vector Berita Terbaru $(\mathrm{BT})=0.06$ diperoleh dari $((0.33 / 7.57)+(0.5 / 10.49)+(0.33 / 4.32)+$ $(0.5 / 6.66)+(2 / 23.5)+(2 / 20)+(2 / 26)+(0.5 / 11.33)+(1 / 18.5)+(0.25 / 14.41) * 1 / 10$

m. Priority Vector Trusmark $(\mathrm{T})=0.09$ diperoleh dari $((0.33 / 7.57)+(0.5 / 10.49)+(0.3 / 4.32)+(0.5 / 6.66)+(3 / 23.5)$ $+(3 / 20)+(2 / 26)+(0.5 / 11.33)+(4 / 18.5)+(1 / 14.41) * 1 / 10$

n. Prioity Vector menunjukan bobot dari masing-masing kriteria, jadi dalam hal ini Gratis Ongkos Kirim (GOK) merupakan bobot tertinggi/terpenting dalam kriteria memilih toko daring terbaik, disusul Nomor Telepon dan Sistem Pembayaran, hingga yang terakhir adalah Toko Finder.

o. Setelah mendapatkan bobot untuk setiap kriteria (yang ada pada kolom Priority Vector), maka selanjutnya mengecek apakah bobot yang dibuat konsisten atau tidak. Untuk hal ini, yang pertama dilakukan adalah menghitung Principal EigenValue (max) matrix.

p. Principal EigenValue (max) matrix perhitungannya dengan cara menjumlahkan hasil perkalian antara jumlah dan priority vector.

q. Principal Eigen Value $(\max ) \rightarrow(7.57 \times 0.15)+(10.49 \times 0.11)+(4.32 \times 0.21)+(6.66 \times 0.15)+(23.5 \times 0.04)+$ $(20 \times 0.05)+(26 \times 0.03)+(11.33 \times 0.09)+(18.5 \times 0.06)+(14.41 \times 0.09)=10.72$

r. Menghitung Consistency Index (CI) dengan rumus $\mathrm{CI}=(\max -\mathrm{n}) /(\mathrm{n}-1)$, untuk n $=10, \mathrm{CI}=(10.72-10) /(10-1)$ $=0.08$. CI sama dengan nol koma nol satu tiga berarti pembobotan yang dilakukan sangat konsisten

S. Menghitung Consistency Ratio $(C R)$ diperoleh dengan rumus $\mathrm{CR}=\mathrm{CI} / \mathrm{RI}$, nilai RI bergantung pada jumlah kriteria seperti pada tabel 7 berikut:

Tabel 7. Nilai Indeks Random Dari Kriteria

\begin{tabular}{cc}
\hline Ukuran Matriks & Nilai RI \\
\hline 1.2 & 0.00 \\
3 & 0.58 \\
4 & 0.90 \\
5 & 1.12 \\
6 & 1.24 \\
7 & 1.32 \\
8 & 1.41 \\
9 & 1.45 \\
10 & 1.49 \\
11 & 1.51 \\
12 & 1.48 \\
13 & 1.56 \\
14 & 1.57 \\
15 & 1.59 \\
\hline
\end{tabular}

Jadi untuk $\mathrm{n}=10$, maka $\mathrm{RI}=1.49$

$\mathrm{CR}=\mathrm{CI} / \mathrm{RI}=0.08 / 1.49=0.05$.

Jika hasil perhitungan $\mathrm{CR}$ lebih kecil atau sama dengan $10 \%(0.1)$, ketidakkonsistenan masih bisa diterima, sebaliknya jika lebih besar dari $10 \%$, tidak bisa diterima.

Proses perhitungan dengan metode ANP pada tabel 5 menjelaskan bahwa kriteria Gratis Ongkos Kirim dengan bobot tertinggi 0.21 adalah sebagai prioritas utama, selanjutnya Sistem Pembayaran dengan bobot 0.15 , kemudian Nomor Telepon/Chating Online, Produk Popular, Merk Produk, Trusmark, Berita Terbaru, Sosial Media Link, Logo dan yang terakhir Toko Finder. Dengan perhitungan metode ANP bobot alternatif dapat ditentukan. Kemudian proses perhitungan yang sama dapat dilakukan untuk menentukan bobot prioritas antar alternaif, sehingga hasil dari keseluruhan perhitungan dapat terlihat pada tabel 8.

3. Bobot Prioritas

Tabel 8. Bobot Prioritas Global Tingkat Alternatif (ANP)

\begin{tabular}{lcccc}
\hline Kriteria & Bobot & Buka Lapak & Shopee & Lazada \\
\hline $\begin{array}{l}\text { Nomor telepon/Chating } \\
\text { Online }\end{array}$ & 0.15 & 0.37 & 0.38 & 0.25 \\
\hline
\end{tabular}


JURNAL MEDIA INFORMATIKA BUDIDARMA, Vol 3, No 4, Oktober 2019

ISSN 2614-5278 (media cetak)

ISSN 2548-8368 (media online)

Hal 254-260 | DOI: $10.30865 / \mathrm{mib} . v 3 i 4.1373$

\begin{tabular}{lcccc}
\hline Kriteria & Bobot & Buka Lapak & Shopee & Lazada \\
\hline Produk Popular & 0.11 & 0.37 & 0.40 & 0.23 \\
Gratis Ongkos Kirim & 0.21 & 0.37 & 0.38 & 0.25 \\
Sistem Pembayaran & 0.15 & 0.39 & 0.36 & 0.26 \\
Logo & 0.04 & 0.37 & 0.39 & 0.24 \\
Sosial Media Link & 0.05 & 0.38 & 0.37 & 0.24 \\
Toko Finder & 0.03 & 0.37 & 0.38 & 0.25 \\
Merk Produk & 0.09 & 0.36 & 0.38 & 0.27 \\
Berita Terbaru & 0.06 & 0.38 & 0.39 & 0.23 \\
Trusmark & 0.09 & 0.37 & 0.38 & 0.25 \\
Bobot Prioritas & 1.00 & 3.73 & 3.80 & 2.47 \\
\hline
\end{tabular}

Berdasarkan hasil pengolahan data pada tabel 8, masing-masing bobot kriteria dalam hal ini mengandung arti bahwa kriteria Gratis Ongkos Kirim merupakan kriteria yang terpenting diantara kriteria yang lain. Sedangkan hasil evaluasi alternatif yang memiliki bobot prioritas yang paling tinggi adalah alternatif Shopee. Oleh karena itu Shopee dipilih sebagai toko terbaik di lingkungan mahasiswa Politeknik Ganesha Medan. Shopee memiliki bobot prioritas sebesar 3.80, Buka Lapak sebesar 3.73, Lazada sebesar 2.47.

\section{IMPLEMENTASI}

\begin{tabular}{|c|c|c|c|c|c|c|}
\hline Graphical & a) Verbal Matrix & Questionnaire Direct & & & & \\
\hline \multicolumn{7}{|c|}{$\begin{array}{l}\text { Comparisons wrt "Toko Daring Terbaik" node in "Kriteria" cluster } \\
\text { Sosial Media Link is equally to moderately more important than Logo }\end{array}$} \\
\hline 1. & Berita Terbaru & 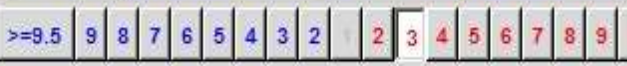 & $>=9.5$ & No comp. & Gratis Ongkos K & \\
\hline 2. & Berita Terbaru & 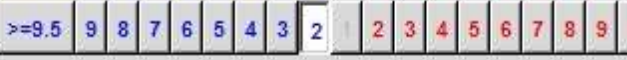 & $>=9.5$ & No comp. & Logo & \\
\hline 3. & Berita Terbaru & 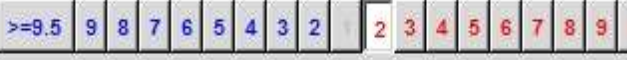 & $>=9.5$ & No comp. & Merk Produk & \\
\hline 4. & Berita Terbaru & \begin{tabular}{l|l|l|l|l|l|l|l|l|l|l|l|l|l|l|l|l|l|}
$s=9.5$ & 9 & 8 & 7 & 6 & 5 & 4 & 3 & 2 & & 2 & 3 & 4 & 5 & 6 & 7 & 8 & 9 \\
\end{tabular} & $x=9.5$ & No comp. & Nomor Telpon & \\
\hline 5. & Berita Terbaru & 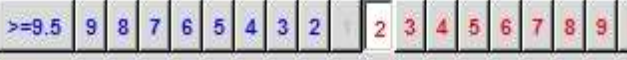 & $>=9.5$ & No comp. & Produk Popular & \\
\hline 6. & Berita Terbaru & 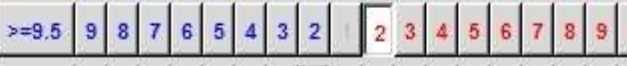 & $>=9.5$ & No comp. & Sistem Pernbayar & \\
\hline 7. & Berita Terbaru & \begin{tabular}{l|l|l|l|l|l|l|l|l|l|l|l|l|l|l|l|l|}
$s=9.5$ & 9 & 8 & 7 & 6 & 5 & 4 & 3 & 2 & 2 & 3 & 4 & 5 & 6 & 7 & 8 & 9 \\
\end{tabular} & $>=9.5$ & No comp. & Sosial Media Li & \\
\hline 8. & Berita Terbaru & 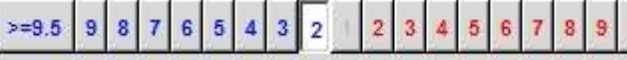 & $x=9.5$ & No comp. & Toko Finder & \\
\hline 9. & Berita Terbaru & 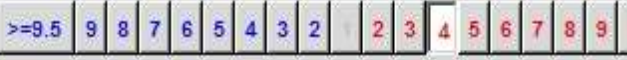 & $>=9.5$ & No comp. & Trustmark & \\
\hline 10. $\mathrm{Gra}$ & ratis Ongkos $\mathrm{K}$ - & \begin{tabular}{l|l|l|l|l|l|l|l|l|l|l|l|l|l|l|l|l|}
$s=9.5$ & 9 & 8 & 7 & 6 & 5 & 4 & 3 & 2 & & 2 & 3 & 4 & 5 & 6 & 7 & 8 \\
\end{tabular} & $x=9.5$ & No comp. & Logo & \\
\hline 11. Gra & ratis Ongkos K - & 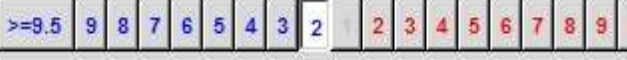 & $>=9.5$ & No comp. & Merk Produk & \\
\hline 12. $\mathrm{Gra}$ & ratis Ongkos K & 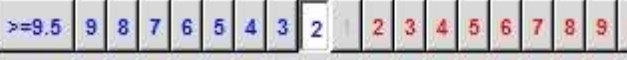 & $>=9.5$ & No comp. & Nomor Telpon & \\
\hline 13. Gra & ratis Ongkos K - & \begin{tabular}{l|l|l|l|l|l|l|l|l|l|l|l|l|l|l|l|l|}
$>=9.5$ & 9 & 8 & 7 & 6 & 5 & 4 & 3 & 2 & & 2 & 3 & 4 & 5 & 6 & 7 & 8 \\
\end{tabular} & $>=9.5$ & No comp. & Produk Popular & \\
\hline 14. Gra & ratis Ongkos $\mathrm{K}^{\sim}$ & \begin{tabular}{l|l|l|l|l|l|l|l|l}
$s=9.5$ & 9 & 8 & 7 & 6 & 5 & 4 & 3 & 2 \\
\end{tabular} & $x=9.5$ & No comp. & Sistem Pernbayar & \\
\hline 15. Gra & ratis Ongkos K & 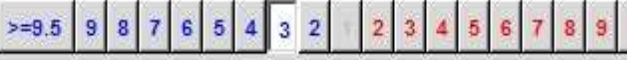 & $>=9.5$ & No comp. & Sosial Media Li & \\
\hline 16. $\mathrm{Gra}$ & ratis Ongkos K & 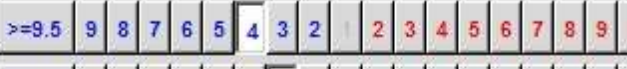 & $>=9.5$ & No comp. & Toko Finder & \\
\hline 17. Gra & ratis Ongkos K & \begin{tabular}{l|l|l|l|l|l|l|l|l|l|l|l|l|l|l|l|l|}
$>=9.5$ & 9 & 8 & 7 & 6 & 5 & 4 & 3 & 2 & & 2 & 3 & 4 & 5 & 6 & 7 & 8 \\
\end{tabular} & $>=9.5$ & No comp. & Trustmark & \\
\hline 18. & Logo & 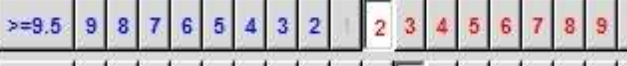 & $x=9.5$ & No comp. & Merk Produk & \\
\hline 19. & Logo & 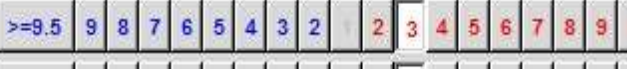 & $>=9.5$ & No comp. & Nomor Telpon & \\
\hline 20. & Logo & 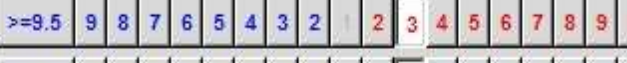 & $x=9.5$ & No comp. & Produk Popular & \\
\hline 21. & Logo & 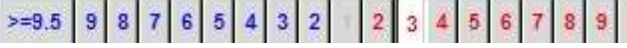 & $>=9.5$ & No comp. & Sistem Pembayar & \\
\hline
\end{tabular}

Gambar 1. Perbandingan antar kriteria 


\begin{tabular}{|c|c|c|}
\hline Normal $\longrightarrow$ & & Hybrid - \\
\hline \multicolumn{3}{|c|}{ Inconsistency: 0.04754} \\
\hline Berita $\mathrm{Te} \sim$ & & 0.05978 \\
\hline Gratis On & & 0.21195 \\
\hline Logo & & 0.04084 \\
\hline Merk Prod & & 0.09385 \\
\hline Nomor Tel & & 0.15192 \\
\hline Produk Po & & 0.11332 \\
\hline Sistem $\mathrm{Pe} \sim$ & & 0.15101 \\
\hline Sosial Me & & 0.05111 \\
\hline Toko Find - & & 0.03446 \\
\hline Trustmark & & 0.09175 \\
\hline
\end{tabular}

Gambar 2. Hasil proses perbandingan antar kriteria

\section{KESIMPULAN}

Model pengambilan keputusan yang digunakan adalah Analytic Network Process (ANP). Model ini digunakan karena sesuai dengan kondisi dimana terdapat keterkaitan antar subkriteria. Berdasarkan hasil pengolahan data dengan menggunakan model ANP diperoleh hasil sebagai berikut: kriteria Gratis Ongkos Kirim yang memiliki bobot tertinggi 0.21 sebagai prioritas utama. diikuti oleh Sistem Pembayaran dengan bobot 0.15, kemudian Nomor Telepon/Chating Online 0.15, Produk Popular 0.11, Merk Produk 0.09, Trusmark 0.09, Berita Terbaru 0.06, Sosial Media Link 0.05, Logo 0.04 dan yang terakhir Toko Finder 003. Dengan perhitungan metode ANP bobot alternatif dapat ditentunkan. Alternatif Shopee dengan bobot 3.80 sebagai proritas utama, kemudian Buka Lapak dengan bobot 3.73 dan yang terakhir Lazada dengan bobot 2.47 .

\section{REFERENCES}

[1] Muhammad Yusuf dan Ahmad Yusuf, 1 Jam Membuat Toko Online dengan Joomla-Virtuemart, Yogyakarta, Expert, 2012 , hlm. 1.

[2] https://www.kompasiana.com/www.bhinneka.com/59b25877085ea65943594dc2/sejarah-e-commerce-indonesia-apa-yang-telah-danakan-terjadi?page=all $(8$ September 2017)

[3] https://www.cnnindonesia.com/teknologi/20190201173813-185-365769/netizen-indonesia-paling-gemar-belanja-online (4 Februari 2019)

[4] https://id.wikipedia.org/wiki/Sistem_pendukung_keputusan (6 Juni 2019)

[5] Saaty TL. 2008. Decision Making with The Analytic Hierarchy Process. Int. J. Services Sciences 1: 83-98

[6] Romindo, “Analisa Perbandingan Metode ANP dan SAW Dalam Menentukan Mahasiswa Terbaik," JIPN (Journal Of Informatics Pelita Nusantara) Volume 4 Nomor 1, Maret 2019 ISSN: 2541-3724. 